\title{
Urgent Proposals for Disinfecting Hospital Wastewaters during COVID-19 Pandemic
}

\author{
Djamel Ghernaout ${ }^{1,2^{*}}$, Noureddine Elboughdiri ${ }^{1,3}$ \\ ${ }^{1}$ Chemical Engineering Department, College of Engineering, University of Ha'il, Ha'il, Saudi Arabia \\ ${ }^{2}$ Chemical Engineering Department, Faculty of Engineering, University of Blida, Blida, Algeria \\ ${ }^{3}$ Département de Génie Chimique de Procédés, Laboratoire Modélisation, Analyse, et Commande des systèmes, Ecole Nationale \\ d’Ingénieurs de Gabès (ENIG), Gabès, Tunisia \\ Email: *djamel_andalus@hotmail.com
}

How to cite this paper: Ghernaout, D. and Elboughdiri, N. (2020) Urgent Proposals for Disinfecting Hospital Wastewaters during COVID-19 Pandemic. Open Access Library Journal, 7: e6373.

https://doi.org/10.4236/oalib.1106373

Received: April 29, 2020

Accepted: May 15, 2020

Published: May 18, 2020

Copyright ( 2020 by author(s) and Open Access Library Inc.

This work is licensed under the Creative

Commons Attribution International

License (CC BY 4.0).

http://creativecommons.org/licenses/by/4.0/

(c) (i) Open Access

\begin{abstract}
Hospitals are significant sources of contaminants derived from the diagnostic, laboratory, and research activities as well as medicine excretion by patients, which comprise active components of drugs and metabolite, chemicals, residues of pharmaceuticals, radioactive markers, iodinated contrast media, etc. Discharging hospital wastewater, especially those without convenient treatment could reveal the public in danger of infection. Particularly, below the Coronavirus Disease 2019 (COVID-19) pandemic context in China and the world, it is vital to avoid the health dangers to humans and nature. This work summaries scientific propositions for management, technology selection, and operation of hospital wastewater disinfection in China, which is crucial for suggesting worldwide disinfection planning for hospital wastewater during COVID-19 pandemic. Further, this work briefly reviews some techniques used for killing viruses such as photocatalytic methods and ferrate(IV). Numerous novel signs of progress have as well been performed in hospital wastewater treatment engineering, like radiation disinfection technique, reverse polymerization disinfection process, plasma disinfection method, and thermal gasification disinfection procedure.
\end{abstract}

\section{Subject Areas}

Chemical Engineering \& Technology, Public Health

\section{Keywords}

COVID-19 Pandemic, Coronavirus, Hospital Wastewater, Disinfection, Chlorination, Disinfection By-Products (DBPs) 


\section{Introduction}

Hospitals are primary sources of contaminants followed from the diagnostic, laboratory, and research activities as well as medicine excretion by patients, which include active component of drugs and metabolite, chemicals, residues of pharmaceuticals, radioactive markers, iodinated contrast media, etc. [1] [2]. Further, it is evaluated that $75 \%$ of the wastes generated by hospitals are general health care wastes, while the remaining $25 \%$ are regarded as hazardous infectious waste [1]. Incorrect disposal of infectious hospital wastes and wastewater can provoke grave hazards to public health and nature [3] [4] [5].

An unknown case of pneumonia was first reported in Hubei, China [6]. By January $7^{\text {th }}, 2020$, Chinese scientists had isolated a Severe Acute Respiratory Syndrome Coronavirus 2 (SARS-CoV-2) from patients in Wuhan [7]. Following the severe acute respiratory syndrome coronavirus (SARS-CoV-1) outbreak in 2002 and the Middle East respiratory syndrome coronavirus (MERS-CoV) outbreak in 2012, SARS-CoV-2 is the third coronavirus to surface during these two decades, which has put global public health institutions on high alert [8] [9]. The transmission routes of SARS-CoV-2 comprise droplet transmission and contact transmission; airborne transmission may be possible in specific circumstances and settings in which procedures or support treatments that generate aerosols are performed [1].

The drainage of hospital wastewaters mostly those without suitable treatment could reveal the public in danger of infection. Indeed, below the COVID-19 pandemic context in the globe, it is vital to decrease the health dangers to the public and nature. Therefore, it is obligatory to suitably disinfect the hospital wastewater prior to being transported or discharged. Methodical researches regarding the disinfection of hospital wastewaters, particularly distinct disinfection propositions throughout the COVID-19 pandemic, stay scarce until now [1]. Consequently, this work focuses on disinfection techniques for the treatment of hospital wastewater and discusses propositions for hospital wastewater disinfection during the COVID-19 pandemic in the world.

\section{Hospital Wastewater Disinfection}

Disinfection techniques using ozone, ultraviolet (UV) light, liquid chlorine, chlorine dioxide, and sodium hypochlorite are usually applied for killing pathogens in hospital wastewater [10] [11] [12]. Figure 1 illustrates the wastewater disinfection strategy in the hospital [1]. A disinfection technique possesses distinctive interests and drawbacks (Table 1). Employing a particular kind of disinfection technology has to be decided through taking into account simultaneously economic and feasible details, like the quantity of wastewater, safety circumstances, the supply of disinfectants, investment and operation prices, etc. (Figure 2) [1].

\subsection{Chlorination Pretreatment}

Bleaching powder is frequently utilized for the chlorination pre-treatment [1]. 


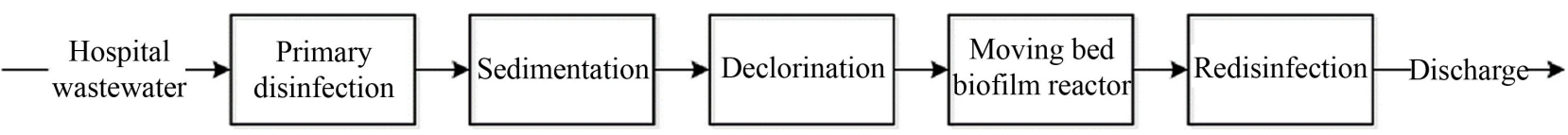

Figure 1. Flow chart of hospital wastewater disinfection technique [1].

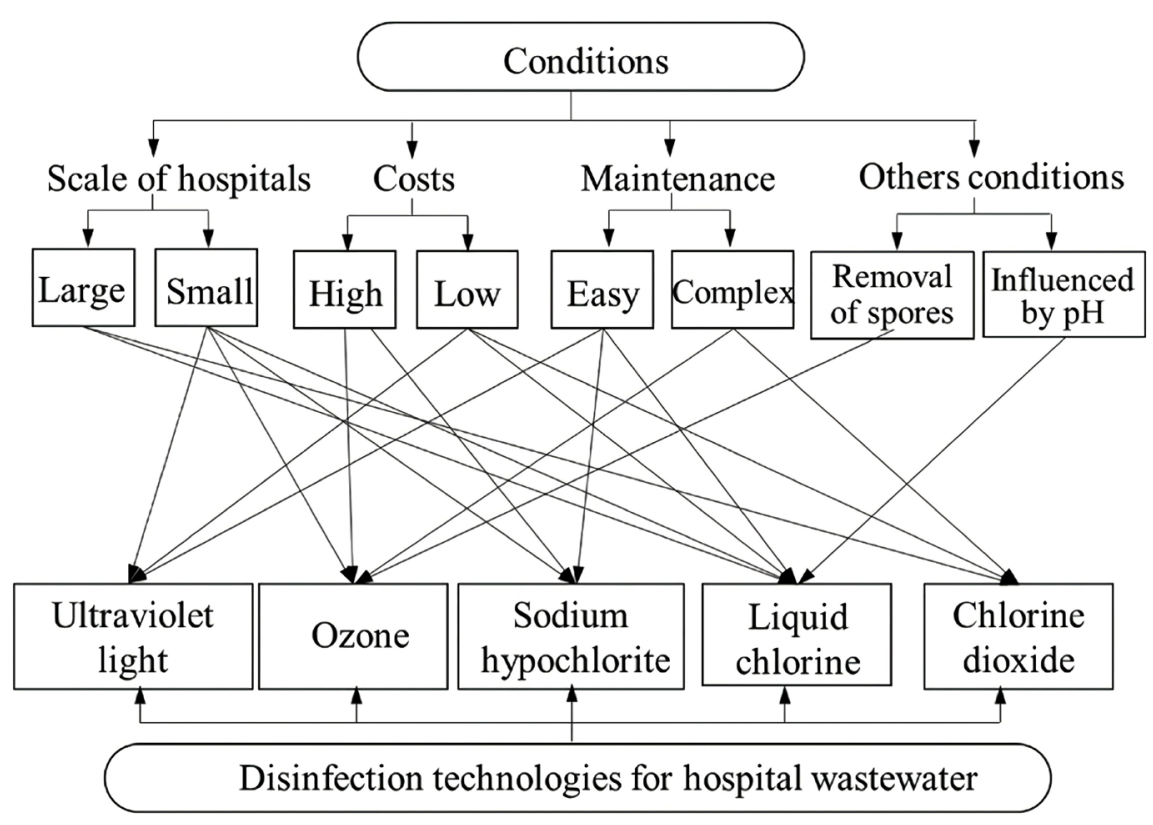

Figure 2. Selection of disinfection techniques for hospital wastewater in varying strategies [1].

Table 1. Comparison of disinfection techniques for hospital wastewater [1] [13] [14] [15].

\begin{tabular}{lll}
\hline Disinfection technology & \multicolumn{1}{c}{ Interests } & \multicolumn{1}{c}{ Drawbacks } \\
\hline Liquid chlorine & Low energy consumption & $\begin{array}{l}\text { High storage risk } \\
\text { UV light }\end{array}$ \\
Low investment and operation costs & $\begin{array}{l}\text { Inadequate depth of penetration } \\
\text { and occupational health risks }\end{array}$ \\
Chlorine dioxide & $\begin{array}{l}\text { High efficiency and low operation } \\
\text { costs }\end{array}$ & $\begin{array}{l}\text { Inconvenient storage and } \\
\text { transport }\end{array}$ \\
Sodium hypochlorite & $\begin{array}{l}\text { Low toxicity, simple equipment, stable } \\
\text { operation, easy control, and low } \\
\text { operation and preparation costs }\end{array}$ & $\begin{array}{l}\text { High energy consumption, } \\
\text { strong corrosiveness, and high } \\
\text { pollution }\end{array}$ \\
& $\begin{array}{l}\text { The ability of decoloring and } \\
\text { deodorizing and quick } \\
\text { decomposition of microorganisms }\end{array}$ & $\begin{array}{l}\text { High operation costs and } \\
\text { hazardous disinfection } \\
\text { by-products (DBPs) }\end{array}$ \\
Ozone & &
\end{tabular}

For each ward and restroom of an infectious disease hospital or the infectious disease area of a general hospital, $1 \mathrm{~kg}$ of bleaching powder containing $25 \%$ of available chlorine per 10 beds should be added 3 to 4 times before further disinfection. The optimal addition time is at the end of the peak period of the restroom use. The added bleaching powder has to be flushed into the septic tank with flowing water and the residual chlorine has to be measured at the outlet of septic tank in case of violation of the water quality standard [1]. 


\subsection{Chlorine-Containing Disinfectants}

Chlorine is a type of powerful oxidizer [16] [17] [18], which is one of the earliest employed disinfection agents in disinfecting hospital wastewater [19]. When utilizing chlorine as the disinfectant, a vacuum siphon fixed-ratio chlorine dosing setup is frequently adopted in the hospital wastewater treatment [20] [21] [22] system. The pipes of the chlorination [23] [24] system are installed in open areas, and buried pipes are located in pipe trenches with good support and sufficient slope. When the water collection pipe in the hospital wastewater treatment [25] [26] [27] system is higher than the public wastewater pipe outside the hospital or the water level (usually a height difference of $600 \mathrm{~mm}$ is required), a siphon-type fixed-ratio chlorine disinfection system could be used. When wastewater needs to be lifted in order to be discharged, a wastewater pump is required to be set up in front of the disinfection mixture contact tank. The disinfectant addition equipment and the lift pump could operate synchronously [1]. The water level of the water collection tank controls the automatic activation of the wastewater pump and the simultaneous operation of the dosing system. Usually, $30 \mathrm{mg} / \mathrm{L}-50 \mathrm{mg} / \mathrm{L}$ and $15 \mathrm{mg} / \mathrm{L}-25 \mathrm{mg} / \mathrm{L}$ chlorine are injected into wastewater following primary treatment and wastewater after secondary treatment, respectively [1]. Whilst the real quantity of chlorine introduced into the wastewater can be regulated following the residual chlorine remaining in the outlet of the wastewater treatment [28] [29] [30] system and the quantity of reducing substances in the wastewater. The most important reaction of chlorine disinfection is [1]:

$$
\mathrm{Cl}_{2}+\mathrm{H}_{2} \mathrm{O}=\mathrm{HClO}+\mathrm{HCl}
$$

\subsubsection{Liquid Chlorine}

When employing liquid chlorine for disinfecting wastewater, a vacuum chlorinator should be utilized and the outlet of the chlorine injection pipe must be submerged in the wastewater [1]. It is severely forbidden to directly inject chlorine to the wastewater without a chlorinator or employing pipes that are not resistant to chlorine gas corrosion, like polyvinyl chloride (PVC), and metal pipes like copper, iron, and other pipes which are not resistant to chlorine solutions. Copper pipes and hard PVC pipes have to be utilized to transport chlorine gas and chlorine-containing disinfectant solutions, respectively [31]. Because of comparatively elevated storage danger, the liquid chlorine disinfection method remains not convenient in regions with a high population [1].

\subsubsection{Chlorine Dioxide}

Heretofore, chlorine dioxide is recognized as one of the efficacious disinfectants with increase oxidization potential even below acidic circumstances [32]. The solubility of chlorine dioxide is five times that of chlorine and the oxidization capability of chlorine dioxide is 2.63 times that of chlorine gas. The quantity of chlorine dioxide utilized to treat hospital wastewater is $1 / 2.5$ that of the available chlorine [1]. The dosing setup of chlorine dioxide for disinfecting wastewater is consistent with the sodium hypochlorite disinfection technology, i.e. a double 
siphon automatic fixed-ratio dosing chlorine system is adopted for chlorine dioxide disinfection. When employing a chlorine dioxide generator, the quantity of chlorine dioxide must be greater than $50 \%$, and it must guarantee secure operation and automatic injection of disinfectants with a definite fraction [33]. Chlorine dioxide can initiate the denaturation of enzyme and protein [34]. It ruins the anabolic pathways of protein and therefore neutralizes the microbe, comprising bacteria, viruses, fungi, spores, and Clostridium botulinum. The chlorine dioxide possesses the capability of decoloring, deodorization, oxidation, and augmenting the oxygen quantity in wastewater. Because of its chemical structure, the chlorine dioxide is unsuitable to be stored or transported, for all that it still possesses merits of lower prices of operation as well as preparation [13].

\subsubsection{Sodium Hypochlorite}

Sodium hypochlorite disinfectant can be produced employing standard $\mathrm{NaClO}$ generator, which can greatly decrease the prices. A double siphon automatic fixed-ratio dosing chlorine system is commonly adopted for sodium hypochlorite disinfection. The quantity of available chlorine in sodium hypochlorite is around $5 \%-20 \%$. The mechanism of sodium hypochlorite disinfection is [1]:

$$
\mathrm{NaClO}+\mathrm{H}_{2} \mathrm{O}=\mathrm{HOCl}+\mathrm{NaOH}
$$

Confronted with different chlorine-containing disinfectants, employing sodium hypochlorite is distinguished with comparatively lower poisoning, easier equipment, more stable working, simpler control, and lower operation and production prices. All these render such a disinfection process handier in smaller scale hospitals [15]. However, sodium hypochlorite disinfection possesses bigger energy consumption, strong corrosiveness, and greater contamination [35]. Consequently, when utilizing on-site manufactured sodium hypochlorite for killing pathogens, a secure and reliable sodium hypochlorite generator with elevated electrical efficiency, low water consumption, low salt and electricity consumption, long operating life, and convenient operation must be used. If raw salt is utilized as the raw material, the salt solution has to be precipitated and filtered before being introduced to the sodium hypochlorite generator. Containers, pipes, equipment, and accessories that contact the sodium hypochlorite solution must be constructed of corrosion-resistant materials [1].

\subsection{Ozone}

As a disinfectant known for its elevated bactericidal impact, ozone has been largely employed in water supply engineering and wastewater treatment [36] [37] [38] especially in developed countries [39] [40] [41]. The wastewater flows into the first-stage sedimentation tank and then flows to the second-stage purification tank after purification. After adequate treatment, it flows to the regulating storage tank. It is then pumped into the contact tower by the sewage pump, and fully exposed to about $15 \mathrm{mg} / \mathrm{L}-20 \mathrm{mg} / \mathrm{L}$ ozone in the tower during $10-15 \mathrm{~min}$ before being discharged. Frequently, a hospital with 300 beds is advised to con- 
struct an ozone treatment system with a wastewater treatment capacity of $18 \mathrm{t} / \mathrm{h}$ to $20 \mathrm{t} / \mathrm{h}$ [1]. Because the ozone disinfection possesses the potential of decoloring and deodorizing, the wastewater after treatment becomes bright and transparent without odor. Furthermore, the molecule structure of ozone is unstable, which implicates that strong oxidative atomic oxygen generated by the decay of the ozone molecule would quickly degrade pathogens, like bacteria and viruses in wastewater. For all that ozone disinfection can ameliorate the water quality in a shorter period with greater performance, the running prices of ozone production remain elevated [42]. In addition, the DBPs [43] [44] [45], which are formed via the chemical response with bromide and iodide, are dangerous to human health [46] [47] [48]. Moreover, an over-dose of ozone is ready to provoke bad smell and additional contamination. Consequently, ozone disinfection stays mostly convenient for the smaller-scale wastewater treatment systems, especially the wastewater treatment systems with comparatively increased effluent quality [1].

\subsection{Ultraviolet (UV) Irradiation}

Ultraviolet light (UV) refers to the electromagnetic wave with a length between $200 \mathrm{~nm}$ and $400 \mathrm{~nm}$ [49] [50] [51]. The UV was first used in the disinfection of drinking water in 1910 [1]. The UV may be classified into four wavebands following distinct wavelengths, comprising UV-A (315 nm - $400 \mathrm{~nm})$, UV-B (280 $\mathrm{nm}-315 \mathrm{~nm}), \mathrm{UV}-\mathrm{C}(200 \mathrm{~nm}-280 \mathrm{~nm})$, and vacuum UV (100 nm - $200 \mathrm{~nm})$ [52]. To that, vacuum UV could not be employed in disinfection since it is absorbed by the wastewater. The bands with a wavelength between $200 \mathrm{~nm}$ and 300 $\mathrm{nm}$ can destroy the structure of both deoxyribonucleic acid (DNA) and ribonucleic acid (RNA) of the bacteria, viruses, and single-celled microorganisms and therefore block the protein synthesis [9] [53] [54]. Therefore, UV-B and UV-C have the best bactericidal impact. The band with wavelength of 253.7 $(\sim 254) \mathrm{nm}$ is optimal for UV disinfection [55]. Juxtaposed with chlorine disinfection, the investment and operation prices of UV disinfection stay considerably smaller. Nevertheless, disinfection with UV-C is occasionally weak because the depth of penetration is unsuitable and there are occupational health dangers [14].

\section{Propositions for Disinfecting Hospital Wastewaters through COVID-19 Pandemic}

A few months ago, during the current COVID-19 pandemic in China, RNA of SARS-CoV-2 has been detected in feces of patients, which prompted worry to the disinfection of wastewater of appointed hospitals [1]. Researchers [1] accepted that transmission could as well happen by means of fomites in the nearest environment around the infected person. Following former investigations, about the pathogen transmission in wastewater system, scientists [1] affirmed that below specific conditions, the wastewater system possesses the capacity to allow airborne transmission of SARS-CoV-2. Such findings are compatible with the 
fact in a study that SARS-CoV-2 from a single stool specimen has been cultured [56]. Further, it is as well mentioned that wastewater discharged from a COVID-19 particular hospital was SARS-CoV-2 RNA positive, showing that the virus might infect the drainage system [1]. On the other hand, disinfecting hospital wastes is as well in an elevated emergency because the waste formation augments exponentially throughout this period, which may augment disease diffusion and provoke a gigantic hazard on both medical staffs and patients without appropriate collection and disinfection [1].

There are only a few pieces of research on the demobilization of SARS-Cov-2 to that extent [9]. However, researchers mentioned that the genome of the SARS-CoV-2 strains are phylogenetically nearest to the bat SARS-related coronaviruses, and the Spike protein has a $78 \%$ nucleotide identity with the human SARS-Co-1 [1]. Because of the resemblances among SARS-CoV-1 and SARS-CoV-2, the SARS-CoV-2 could as well be vulnerable to either ecological agents or disinfectants. Thus, disinfection techniques embraced throughout the SARS epidemic may be utilized as a perfect reference to killing SARS-Cov-2 in hospital wastewater. SARS coronavirus (SARS-CoV-1) can subsist for 2 days, 3 days, and 17 days in the hospital wastewater, stool, and urine at $20^{\circ} \mathrm{C}$, respectively [57]. All SARS viruses can be neutralized in $30 \mathrm{~min}$ at $20^{\circ} \mathrm{C}$ with more than $0.5 \mathrm{mg} / \mathrm{L}$ residual free chlorine or $2.19 \mathrm{mg} / \mathrm{L}$ residual chlorine dioxide left [1]. Scientists juxtaposed disinfection effectiveness of numerous methods and noted that chlorine and UV irradiation were the most performant pursued by chlorine dioxide, for all that efficacy of ozonation was not exemplary. Such a finding was in accord with those observed by Wang et al. [57].

Until January 27, 2020, there have been 1512 COVID-19 designated hospitals all over China [1]. In Wuhan, the local Ministry of Ecology and Environment (MEE) has settled a crisis program for disposal of wastewater from temporary treatment centers, which are freshly constructed COVID-19 specified hospitals for cases with moderate symptoms in Wuhan. Chlorine disinfection (liquid chlorine, chlorine dioxide, and sodium hypochlorite), which has long been employed in hospital wastewater disinfection in China, is embraced in such an agenda. The available chlorine is advised to be about $50 \mathrm{mg} / \mathrm{L}$. For disinfecting the septic tank, the residence period has to be more than $1.5 \mathrm{~h}$ with residual chlorine over 6.5 $\mathrm{mg} / \mathrm{L}$ and fecal coliform colonies less than 100 per liter [1]. Further, UV irradiation [52] and heating [25] are as well proposed for disinfecting wastewater in different COVID-19 selected hospitals due to fewer DBPs and perfect disinfection efficacy [58] [59] [60]. Water standards of wastewater discharged from the hospital have to satisfy the requirements listed in Table 2 [1].

\section{Killing Influenza A Virus H1N1 via Disinfection Method}

Since any patient, health care worker, or visitor is apt to transmit influenza to vulnerable individuals inside hospitals, hospital-acquired influenza has been a clinical worry. Disinfecting and cleaning medical equipment, surgical instruments, 
Table 2. Indicators of disinfection efficacy of hospital wastewater [1].

\begin{tabular}{cc}
\hline Indicator & Value range \\
\hline Fecal coliforms (Most probable number, MPN/L) & $\leq 900$ \\
Enteric pathogens & Not detected \\
Mycobacterium tuberculosis & Not detected \\
Disinfection contact time & $\geq 1.5 \mathrm{~h}$ (Chlorination) \\
& $\geq 0.5 \mathrm{~h}($ Chlorine dioxide method $)$ \\
Total residual chlorine $(\mathrm{mg} / \mathrm{L})$ & $\geq 6.5$ (Chlorination) \\
& $\geq 4.0($ Chlorine dioxide method $)$ \\
\hline
\end{tabular}

and hospital environment stay significant actions to avert transmission of influenza virus from hospitals to persons. Jeong et al. [61] assessed the efficiency of disinfection techniques, which can be readily run at hospitals, in killing influenza A virus H1N1 (H1N1). They assessed the influences of $0.1 \mathrm{~mol} / \mathrm{L} \mathrm{NaOH}, 70 \%$ ethanol, $70 \%$ 1-propanol, solvent/detergent (S/D) using $0.3 \%$ tri (n-butyl)-phosphate and $1.0 \%$ Triton $\mathrm{X}-100$, heat, and ethylene oxide (EO) treatments in neutralizing H1N1. Demobilizing H1N1 was kinetically controlled via the treatment of disinfectants to virus solution. Further, a surface test procedure, which implied drying a quantity of a virus on a surface and then implementing the demobilization processes for $1 \mathrm{~min}$ of contact time, was employed to check the virucidal effectiveness.H1N1 was fully demobilized to unnoticeable degrees in $1 \mathrm{~min}$ of $70 \%$ ethanol, 70\% 1-propanol, and S/D treatments in the surface tests as well as in the suspension tests. $\mathrm{H} 1 \mathrm{~N} 1$ was totally demobilized in $1 \mathrm{~min}$ of $0.1 \mathrm{~mol} / \mathrm{L} \mathrm{NaOH}$ treatment in the suspension tests and as well efficiently demobilized in the surface tests with the log reduction factor of 3.7. H1N1 was demobilized to unnoticeable degrees within $5 \mathrm{~min}, 2.5 \mathrm{~min}$, and $1 \mathrm{~min}$ of heat treatment at $70^{\circ} \mathrm{C}, 80^{\circ} \mathrm{C}$, and $90^{\circ} \mathrm{C}$, respectively in the suspension tests. Also, H1N1 was fully demobilized by EO treatment in the surface tests. Consequently, usual disinfectants, heat, and EO were efficacious in demobilizing H1N1. Such findings were useful in applying efficient disinfecting procedures to avert hospital-acquired infections.

\section{Photocatalytic Killing of Viruses}

Obtaining efficacious disinfection of waterborne pathogens with reduced poisonous DBPs [62] [63] [64] requires an easy, cost-efficient, and environmentally-friendly technology [65] [66] [67] [68]. Lately, photocatalytic water disinfection has magnetized ever-growing worldwide interest thanks to its strong oxidative potential and encouraging capacity in solar energy usage [69] [70] [71]. Among waterborne pathogens, viruses, which have been found with very small sizes, high risks of illness, and resistant to environmental inactivation/decomposition, constitute a grave menace to public health [59] [72] [73]. During the last three decades (Figure 3), attempts have been dedicated to using photocatalysis to reach real viral demobilization [21] [54] [74]. Despite that photocatalysis has been completely examined for killing bacteria, photocatalytic disinfection of viruses 


\section{Photocatalytic Disinfection of Waterborne Viruses}

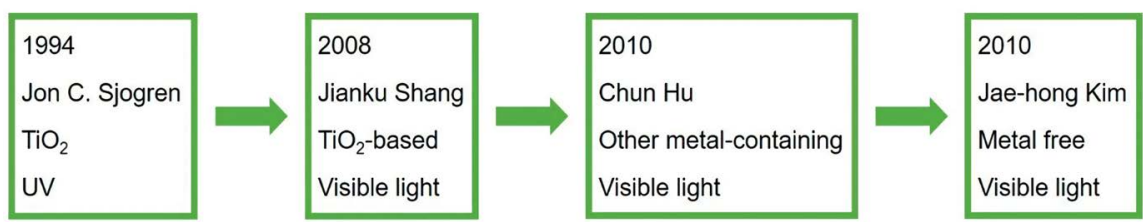

Figure 3. Progresses on typical types of photocatalysts for viral inactivation [75].

with quite different compositions, structures, and resistance to oxidative stress compared to bacteria was not consistently detailed (Figure 4). Zhang et al. [75] suggested a summary of antiviral impacts of a large variety of photocatalysts, comprising $\mathrm{TiO}_{2}$-based, metal-containing (other than $\mathrm{TiO}_{2}$ ), and metal-free photocatalysts. Further, they recapitulated the advance of photocatalytic reactors for viral demobilization to encourage handy utilizations for disinfecting water (Figure 5). Moreover, they discussed the pivotal pathways that dictate the effectiveness of photocatalytic viral disinfection.

Zheng et al. [76] employed bacteriophage f2 and its host E. coli 285 as the model microorganisms and examined the disinfection efficiency of prepared $\mathrm{Cu}-\mathrm{TiO}_{2}$ nanofibers below visible light. They found that the prepared $\mathrm{Cu}-\mathrm{TiO}_{2}$ nanofibers depicted an excellent capability in eliminating bacteriophage $\mathrm{f} 2$ and E. coli below visible light. Initial $\mathrm{pH}$ did not influence the photocatalytic disinfection efficacy importantly. In a particular domain, the reduction performance of bacteriophage $\mathrm{f} 2$ augmented with the elevation of catalyst dosage, light intensity, and temperature; however, it diminished with the elevation of the initial virus level. In virus/bacteria mixed combination, bacteriophage f2 manifested more powerful resistance to photocatalytic oxidation than $E$. coli and the reduction of bacteriophage $\mathrm{f} 2$ was clearly influenced by being mixed with $E$. coli; however, the elimination of $E$. coli nearly stayed unaltered after being mixed with bacteriophage f2. Competitive adsorption in the mixed system contributed to $E$. coli demobilization, whilst the free reactive oxygen species (ROSs) in the bulk phase greatly participated in phage $\mathrm{f} 2$ demobilization.

\section{Ferrate(IV) for Neutralizing Viruses}

In water and wastewater treatment, coagulation [77] [78] [79], oxidation [49] [50] [54], and disinfection [9] [48] [59] are primary methods [64] [68] [80]. A chemical that could be utilized for all the above-mentioned targets is ferrate(VI). Talaiekhozani et al. [81] reviewed ferrate(VI) formation, measurement, stability, mutagenicity, and utilization in coagulation [82] [83] [84], oxidation, and disinfection. Diverse electrochemical devices that could be employed for ferrate(VI) generation have been presented [85] [86] [87].

Ferrate(VI) salt could disinfect water and oxidize organic and inorganic pollution concurrently [81] [88]. Indeed, ferrate(VI) could neutralize pathogens in two fashions: 1) as ferrate(VI) is a powerful oxidizer, it could oxidize cell wall, 


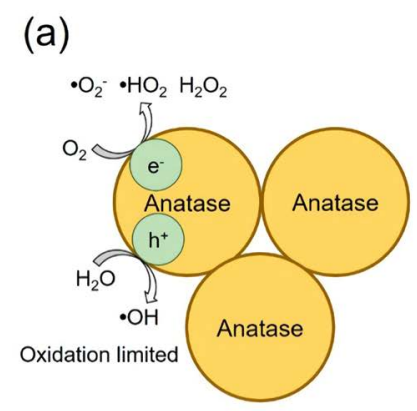

Reduction limited

$\cdot \mathrm{O}_{2} \cdot \cdot \mathrm{HO}_{2} \mathrm{H}_{2} \mathrm{O}_{2}$
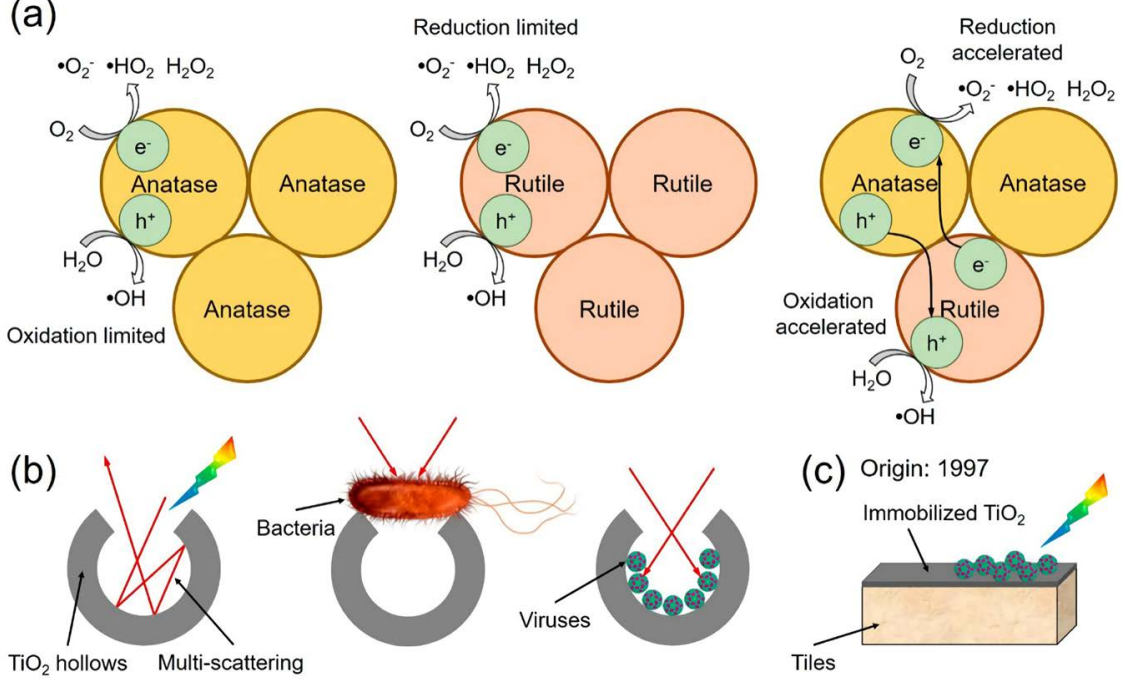

(b)

$\mathrm{TiO}_{2}$ hollows Multi-scattering (c) Origin: 1997

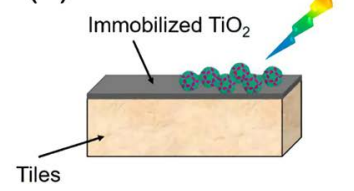

Figure 4. $\mathrm{TiO}_{2}$ photocatalysts for viral demobilization below UV irradiation: (a) impact of $\mathrm{TiO}_{2}$ crystalline structures, (b) effect of $\mathrm{TiO}_{2}$ specific morphology (bacterium Escherichia colivs. phage $\mathrm{Q} \beta$ ), and (c) immobilized $\mathrm{TiO}_{2}$ used for viral inactivation [75].

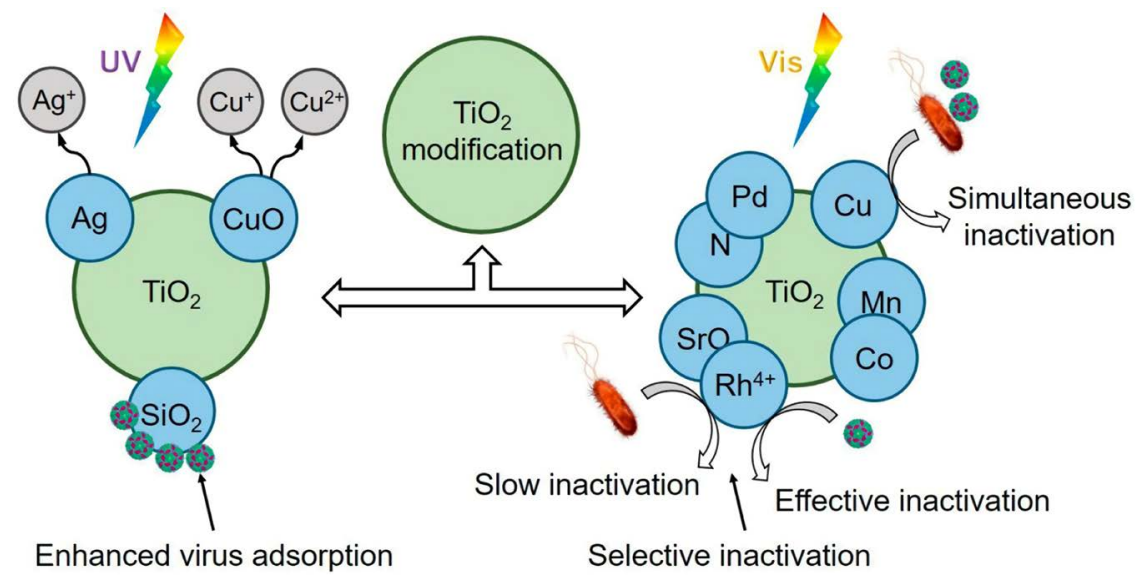

Figure 5. Typical improvements of $\mathrm{TiO}_{2}$ photocatalysts for ameliorated viral demobilization [75].

protoplasm, DNA, and different vital microorganism organs which eliminates them at once [37] [38]. 2) Ferrate(VI) is progressively transformed to Fe(III) [89] [90] [91] which is a powerful coagulant; thus, colloids comprising microbes are coagulated and eliminated from the water [92] [93] [94]. Small amounts of ferrate(VI) could coagulate colloids and oxidize soluble pollutants simultaneously [74] [80] [81]. Such features oblige potassium ferrate as a suitable replacement for diverse conventional disinfectants [74] [80] [95]. In the dosage varying from 0 to $50 \mathrm{mg} / \mathrm{L}$, ferrate(VI) could neutralize all microbes in water [81]. Ferrate(VI) could totally disinfect water carrying $E$. coli [81]. Concerning viruses elimination, numerous researches have established the capacity of ferrate(VI) for killing such pathogens. The potential of ferrate(VI) to remove the $\mathrm{f} 2$ coliphage virus was proved [81]. Indeed, $99 \%$ of $\mathrm{f} 2$ coliphage is neutralized in water carrying $1 \mathrm{mg} / \mathrm{l}$ ferrate (VI), pH of 7.8 after $22 \mathrm{~min}$. Such a contact period is decreased to 5.7 and 
$0.77 \mathrm{~min}$ when $\mathrm{pH}$ is diminished to 6.9 and 5.9, respectively. Further, $99.9 \%$ elimination yield was reached with ferrate(VI) injection of $10 \mathrm{mg} / \mathrm{L}, \mathrm{pH}$ of 7.8 , and the retention period of $30 \mathrm{~min}$. Such a green product remains much more efficacious as a disinfectant than chlorine, whilst no potassium ferrate sediments were found in the disinfection region. The production of sediments in the disinfection method stays an additional major drawback of employing chlorine besides DBPs formation.

\section{Conclusion}

Hospital wastewater (as well as the sludge) must be treated and disinfected completely prior to discharge [1]. Without disinfection, they should not be left to be randomly discharged or utilized as agricultural fertilizers. Employing any infiltration wells/pits to discharge wastewater and sludge, or the discharge into sanitary protection zone of drinking water sources must as well be harshly barred. Further, the government must adopt actions to ameliorate the management of hospital wastewater, particularly throughout the COVID-19 pandemic. The hospital must set up a recycling system and assign special personnel to take charge, and strengthen the management of each department to ban waste loss. Personnel implicated in the disposal of disposable medical supplies must be qualified and strengthened in personal protection. Lately, several novel signs of progress have as well been performed in hospital wastewater treatment engineering, like radiation disinfection technique, reverse polymerization disinfection process, plasma disinfection method, and thermal gasification disinfection procedure. Such technologies possess important promotion value; however, because of the elevated investment costs, such techniques have not been employed at a large scale. With ameliorating hospital wastewater disinfection processes, the prices of disinfection will persist to lower, and side contamination to nature will be progressively dominated. In the course of the disinfection, the ecological contamination or influences on human health could be greatly decreased if the procedure accurately complies with the requirements. With a view to improving more secure, efficient, economical disinfection technologies, the local natural and real circumstances must be taken into account in the next investigations [1].

\section{Acknowledgements}

This research has been funded by the Research Deanship of University of Ha'il, Saudi Arabia, through the Project RG-191190.

\section{Conflicts of Interest}

The authors declare no conflicts of interest regarding the publication of this paper.

\section{References}

[1] Wang, J., Shen, J., Ye, D., Yan, X., Zhang, Y., Yang, W., Li, X., Wang, J., Zhang, L. and Pan, L. (2020) Disinfection Technology of Hospital Wastes and Wastewater: 
Suggestions for Disinfection Strategy during Coronavirus Disease 2019 (COVID-19) Pandemic in China. Environmental Pollution. https://doi.org/10.1016/j.envpol.2020.114665

[2] Verlicchi, P., Galletti, A., Petrovic, M. and Barceló, D. (2010) Hospital Effluents as a Source of Emerging Pollutants: An Overview of Micropollutants and Sustainable Treatment Options. Journal of Hydrology, 389, 416-428. https://doi.org/10.1016/j.jhydrol.2010.06.005

[3] Ghernaout, D. and Elboughdiri, N. (2020) Antibiotics Resistance in Water Mediums: Background, Facts, and Trends. Applied Engineering, 4, 1-6. https://doi.org/10.4236/oalib.1106003

[4] Ghernaout, D. and Elboughdiri, N. (2020) Removing Antibiotic-Resistant Bacteria (ARB) Carrying Genes (ARGs): Challenges and Future Trends. Open Access Library Journal, 7, e6003. https://doi.org/10.4236/oalib.1106003

[5] Ghernaout, D. and Elboughdiri, N. (2020) Should We Forbid the Consumption of Antibiotics to Stop the Spread of Resistances in Nature? Open Access Library Journal, 7, e6138.

[6] Chan, J.F.-W., Yuan, S., Kok, K.-H., To, K.K.-W., Chu, H., Yang, J., Xing, F., Liu, J., Yip, C.C.-Y., Poon, R.W.-S., Tsoi, H.-W., Lo, S.K.-F., Chan, K.-H., Poon, V.K.-M., Chan, W.-M., Ip, J.D., Cai, J.-P., Cheng, V.C.C., Chen, H., Hui, C.K.-M. and Yuen, K.-Y. (2020) A Familial Cluster of Pneumonia Associated with the 2019 Novel Coronavirus Indicating Person-to-Person Transmission: A Study of a Family Cluster. The Lancet, 395, 514-523. https://doi.org/10.1016/S0140-6736(20)30154-9

[7] Wang, C., Horby, P.W., Hayden, F.G. and Gao, G.F. (2020) A Novel Coronavirus Outbreak of Global Health Concern. The Lancet, 395, 470-473.

https://doi.org/10.1016/S0140-6736(20)30185-9

[8] Munster, V.J., Koopmans, M., van Doremalen, N., van Riel, D. and de Wit, E. (2020) A Novel Coronavirus Emerging in China-Key Questions for Impact Assessment. The New England Journal of Medicine, 382, 692-694. https://doi.org/10.1056/NEJMp2000929

[9] Ghernaout, D. and Elboughdiri, N. (2020) Disinfecting Water: Plasma Discharge for Removing Coronaviruses. Open Access Library Journal, 7, e6314. https://doi.org/10.4236/oalib.1106314

[10] Chen, L., Zhou, H., Yu, B. and Huang, Z.W. (2014) Comparison Study on Hospital Wastewater Disinfection Technology. Advanced Materials Research, 884-885, 41-45. https://doi.org/10.4028/www.scientific.net/AMR.884-885.41

[11] Lizasoain, A., Tort, L.F.L., García, M., Gillman, L., Alberti, A., Leite, J.P.G., Miagostovich, M.P., Pou, S.A., Cagiao, A., Razsap, A., Huertas, J., Berois, M., Victoria, M. and Colina, R. (2018) Human Enteric Viruses in a Wastewater Treatment Plant: Evaluation of Activated Sludge Combined with UV Disinfection Process Reveals Different Removal Performances for Viruses with Different Features. Letters in Applied Microbiology, 66, 215-221. https://doi.org/10.1111/lam.12839

[12] Yu, B., Zhou, Y. and Huang, Z.W. (2014) Research on Simple Disinfection System for Medical Wastewater of Township Hospital. Asian Journal of Chemistry, 26, 3243-3245. https://doi.org/10.14233/ajchem.2014.17501

[13] Fan, D., Tian, Y., Han, L., Liu, Z., Teng, Y. and Li, B. (2017) Catalytic Electrolysis of Sodium Chlorite to Prepare Highly Pure Chlorine Dioxide. Journal of Functional Materials, 48, 9150-9156.

[14] Kühn, K.P., Chaberny, I.F., Massholder, K., Stickler, M. and Erdinger, L. (2003) Disinfection of Surfaces by Photocatalytic Oxidation with Titanium Dioxide and 
UVA Light. Chemosphere, 53, 71-77. https://doi.org/10.1016/S0045-6535(03)00362-X

[15] Yu, J.L., Li, Q. and Yan, S.C. (2013) Design and Running for a Hospital Wastewater Treatment Project. Advanced Materials Research, 777, 356-359. https://doi.org/10.4028/www.scientific.net/AMR.777.356

[16] Ghernaout, D., Alghamdi, A., Aichouni, M. and Touahmia, M. (2018) The Lethal Water Tri-Therapy: Chlorine, Alum, and Polyelectrolyte. World Journal of Applied Chemistry, 3, 65-71. https://doi.org/10.11648/j.wjac.20180302.14

[17] Ghernaout, D. and Elboughdiri, N. (2020) Is Not It Time to Stop Using Chlorine for Treating Water? Open Access Library Journal, 7, e6007.

[18] Ghernaout, D., Naceur, M.W. and Aouabed, A. (2011) On the Dependence of Chlorine By-Products Generated Species Formation of the Electrode Material and Applied Charge during Electrochemical Water Treatment. Desalination, 270, 9-22. https://doi.org/10.1016/j.desal.2011.01.010

[19] Ma, Y.-M., et al. (2010) Application Progress of Hospital Wastewater Treatment Methods. Occupational Health, 26, 1180-1182.

[20] Ghernaout, D. and Elboughdiri, N. (2020) Domestic Wastewater Treatment: Difficulties and Reasons, and Prospective Solutions-China as an Example. Open Access Library Journal, 7, e6141.

[21] Ghernaout, D. and Elboughdiri, N. (2020) Advanced Oxidation Processes for Wastewater Treatment: Facts and Future Trends. Open Access Library Journal, 7, e6139.

[22] Ghernaout, D. and Elboughdiri, N. (2020) On the Treatment Trains for Municipal Wastewater Reuse for Irrigation. Open Access Library Journal, 7, e6088.

[23] Ghernaout, D., Moulay, S., Ait Messaoudene, N., Aichouni, M., Naceur, M.W. and Boucherit, A. (2014) Coagulation and Chlorination of NOM and Algae in Water Treatment: A Review. International Journal of Environmental Monitoring and Analysis, 2, 23-34. https://doi.org/10.11648/j.ijema.s.2014020601.14

[24] Ghernaout, D. (2017) Water Treatment Chlorination: An Updated Mechanistic Insight Review. Chemistry Research Journal, 2, 125-138.

[25] Ghernaout, D. (2013) The Best Available Technology of Water/Wastewater Treatment and Seawater Desalination: Simulation of the Open Sky Seawater Distillation. Green and Sustainable Chemistry, 3, 68-88. https://doi.org/10.4236/gsc.2013.32012

[26] Ghernaout, D., Alshammari, Y. and Alghamdi, A. (2018) Improving Energetically Operational Procedures in Wastewater Treatment Plants. International Journal of Advances in Applied Sciences, 5, 64-72. https://doi.org/10.21833/ijaas.2018.09.010

[27] Al Arni, S., Amous, J. and Ghernaout, D. (2019) On the Perspective of Applying of a New Method for Wastewater Treatment Technology: Modification of the Third Traditional Stage with Two Units, One by Cultivating Microalgae and Another by Solar Vaporization. International Journal of Environmental Sciences \& Natural Resources, 16, Article ID: 555934. https://doi.org/10.19080/IJESNR.2019.16.555934

[28] Ghernaout, D. (2019) Reviviscence of Biological Wastewater Treatment-A Review. Applied Engineering, 3, 46-55.

[29] Ghernaout, D. and Elboughdiri, N. (2019) Upgrading Wastewater Treatment Plant to Obtain Drinking Water. Open Access Library Journal, 6, e5959. https://doi.org/10.4236/oalib.1105959

[30] Ghernaout, D. and Elboughdiri, N. (2020) Electrochemical Technology for Wastewater Treatment: Dares and Trends. Open Access Library Journal, 7, e6020.

[31] Zhu, Z., Wu, C., Zhong, D., Yuan, Y., Shan, L. and Zhang, J. (2014) Effects of Pipe 
Materials on Chlorine-Resistant Biofilm Formation under Long-Term High Chlorine Level. Applied Biochemistry and Biotechnology, 173, 1564-1578. https://doi.org/10.1007/s12010-014-0935-X

[32] Wang, Y. (2016) Study of Wastewater Advanced Treatment and Reclaimed Water Reuse for a Large General Hospital. Meteorological and Environmental Research, 7, 37-39.

[33] Wang, J., Cao, J., Zhang, D. and Yang, Z. (2013) Design and Operation of Hospital Comprehensive Wastewater Treatment Engineering. China Water Wastewater, 29, 74-77.

[34] Ogata, N. (2007) Denaturation of Protein by Chlorine Dioxide: Oxidative Modification of Tryptophan and Tyrosine Residues. Biochemistry, 46, 4898-4911. https://doi.org/10.1021/bi061827u

[35] Emmanuel, E., Keck, G., Blanchard, J.M., Vermande, P. and Perrodin, Y. (2004) Toxicological Effects of Disinfections Using Sodium Hypochlorite on Aquatic Organisms and Its Contribution to AOX Formation in Hospital Wastewater. Environment International, 30, 891-900. https://doi.org/10.1016/j.envint.2004.02.004

[36] Ghernaout, D., Elboughdiri, N. and Ghareba, S. (2020) Fenton Technology for Wastewater Treatment: Dares and Trends. Open Access Library Journal, 7, e6045. https://doi.org/10.4236/oalib.1106045

[37] Ghernaout, D. (2017) Microorganisms' Electrochemical Disinfection Phenomena. EC Microbiology, 9, 160-169.

[38] Ghernaout, D., Alghamdi, A. and Ghernaout, B. (2019) Microorganisms' Killing: Chemical Disinfection vs. Electrodisinfection. Applied Engineering, 3, 13-19.

[39] Chiang, C.-F., Tsai, C.-T., Lin, S.-T., Huo, C.-P. and Lo, K.V. (2003) Disinfection of Hospital Wastewater by Continuous Ozonization. Journal of Environmental Science and Health, Part A, 38, 2895-2908. https://doi.org/10.1081/ESE-120025839

[40] Kist, L.T., Rosa, E.C., Machado, E.L., Camargo, M.E. and Moro, C.C. (2013) Glutaraldehyde Degradation in Hospital Wastewater by Photoozonation. Environmental Technology, 34, 2579-2586. https://doi.org/10.1080/09593330.2013.781200

[41] Ghernaout, D. and Elboughdiri, N. (2020) Towards Enhancing Ozone Diffusion for Water Disinfection-Short Notes. Open Access Library Journal, 7, e6253.

[42] Arslan, A., Topkaya, E., Özbay, B., Özbay, I. and Veli, S. (2017) Application of $\mathrm{O}_{3} / \mathrm{UV} / \mathrm{H}_{2} \mathrm{O}_{2}$ Oxidation and Process Optimization for Treatment of Potato Chips Manufacturing Wastewater. The Water and Environment Journal, 31, 64-71. https://doi.org/10.1111/wej.12227

[43] Ghernaout, D. and Elboughdiri, N. (2020) Strategies for Reducing Disinfection By-Products Formation during Electrocoagulation. Open Access Library Journal, 7, e6076. https://doi.org/10.4236/oalib.1106076

[44] Ghernaout, D. and Elboughdiri, N. (2020) Disinfection By-Products: Presence and Elimination in Drinking Water. Open Access Library Journal, 7, e6140.

[45] Ghernaout, D. (2018) Disinfection and DBPs Removal in Drinking Water Treatment: A Perspective for a Green Technology. International Journal of Advances in Applied Sciences, 5, 108-117. https://doi.org/10.21833/ijaas.2018.02.018

[46] Boucherit, A., Moulay, S., Ghernaout, D., Al-Ghonamy, A.I., Ghernaout, B., Naceur, M.W., Ait Messaoudene, N., Aichouni, M., Mahjoubi, A.A. and Elboughdiri, N.A. (2015) New Trends in Disinfection By-Products Formation upon Water Treatment. Journal of Research \& Developments in Chemistry, 2015, Article ID: 628833. https://doi.org/10.5171/2015.628833 
[47] Ghernaout, D. and Elboughdiri, N. (2020) Controlling Disinfection By-Products Formation in Rainwater: Technologies and Trends. Open Access Library Journal, 7, e6162. https://doi.org/10.4236/oalib.1106162

[48] Ghernaout, D., Elboughdiri, N. and Ghernaout, B. (2020) Trends in Decreasing Disinfection By-Products Formation during Electrochemical Technologies. Open Access Library Journal, 7, e6142. https://doi.org/10.4236/oalib.1106337

[49] Ghernaout, D. (2013) Advanced Oxidation Phenomena in Electrocoagulation Process: A Myth or a Reality? Desalination and Water Treatment, 51, 7536-7554. https://doi.org/10.1080/19443994.2013.792520

[50] Ghernaout, D. (2019) Virus Removal by Electrocoagulation and Electrooxidation: New Findings and Future Trends. Journal of Environmental Science and Allied Research, 85-90.

[51] Ghernaout, D. (2019) Electrocoagulation and Electrooxidation for Disinfecting Water: New Breakthroughs and Implied Mechanisms. Applied Engineering, 3, 125-133.

[52] Ghernaout, D. and Elboughdiri, N. (2020) UV-C/ $\mathrm{H}_{2} \mathrm{O}_{2}$ and Sunlight $/ \mathrm{H}_{2} \mathrm{O}_{2}$ in the Core of the Best Available Technologies for Dealing with Present Dares in Domestic Wastewater Reuse. Open Access Library Journal, 7, e6161. https://doi.org/10.4236/oalib.1106161

[53] Ghernaout, D. and Elboughdiri, N. (2020) Environmental Engineering for Stopping Viruses Pandemics. Open Access Library Journal, 7, e6299.

[54] Ghernaout, D., Elboughdiri, N., Ghareba, S. and Salih, A. (2020) Electrochemical Advanced Oxidation Processes (EAOPs) for Disinfecting Water-Fresh Perspectives. Open Access Library Journal, 7, e6257. https://doi.org/10.4236/oalib.1106257

[55] Meulemans, C.C.E. (1987) The Basic Principles of UV Disinfection of Water. Ozone: Science \& Engineering, 9, 299-314. https://doi.org/10.1080/01919518708552146

[56] Zhang, Y., Chen, C., Zhu, S., Shu, C., Wang, D., Song, J., Song, Y., Zhen, W., Feng, Z., Wu, G., Xu, J. and Xu, W. (2020) Notes from the Field: Isolation of 2019-nCoV from a Stool Specimen of a Laboratory-Confirmed Case of the Coronavirus Disease 2019 (COVID-19). China CDC Weekly, 2, 123-124.

[57] Wang, X.W., Li, J.S., Jin, M., Zhen, B., Kong, Q.X., Song, N., Xiao, W.J., Yin, J., Wei, W., Wang, G.J., Si, B.Y., Guo, B.Z., Liu, C., Ou, G.R., Wang, M.N., Fang, T.Y., Chao, F.H. and Li, J.W. (2005) Study on the Resistance of Severe Acute Respiratory Syndrome-Associated Coronavirus. The Journal of Virological Methods, 126, 171-177. https://doi.org/10.1016/j.jviromet.2005.02.005

[58] Ghernaout, D., Elboughdiri, N., Ghareba, S. and Salih, A. (2020) Disinfecting Water with the Carbon Fiber-Based Flow-Through Electrode System (FES): Towards Axial Dispersion and Velocity Profile. Open Access Library Journal, 7, e6238. https://doi.org/10.4236/oalib.1106238

[59] Ghernaout, D. and Ghernaout, B. (2010) From Chemical Disinfection to Electrodisinfection: The Obligatory Itinerary? Desalination and Water Treatment, 16, 156-175. https://doi.org/10.5004/dwt.2010.1085

[60] Ghernaout, D., Touahmia, M. and Aichouni, M. (2019) Disinfecting Water: Electrocoagulation as an Efficient Process. Applied Engineering, 3, 1-12.

[61] Jeong, E.K., Bae, J.E. and Kim, I.S. (2010) Inactivation of Influenza A Virus H1N1 by Disinfection Process. American Journal of Infection Control, 38, 354-360. https://doi.org/10.1016/j.ajic.2010.03.003

[62] Ghernaout, D. and Elboughdiri, N. (2019) Iron Electrocoagulation Process for Disinfecting Water-A Review. Applied Engineering, 3, 154-158. 
[63] Ghernaout, D. (2019) Disinfection via Electrocoagulation Process: Implied Mechanisms and Future Tendencies. EC Microbiology, 15, 79-90.

[64] Ghernaout, D. and Elboughdiri, N. (2019) Mechanistic Insight into Disinfection Using Ferrate(VI). Open Access Library Journal, 6, e5946.

[65] Ghernaout, D., Aichouni, M. and Touahmia, M. (2019) Mechanistic Insight into Disinfection by Electrocoagulation-A Review. Desalination and Water Treatment, 141, 68-81. https://doi.org/10.5004/dwt.2019.23457

[66] Ghernaout, D. (2019) Greening Electrocoagulation Process for Disinfecting Water. Applied Engineering, 3, 27-31.

[67] Ghernaout, D. and Elboughdiri, N. (2019) Electrocoagulation Process Intensification for Disinfecting Water-A Review. Applied Engineering, 3, 140-147.

[68] Ghernaout, D. and Elboughdiri, N. (2019) Water Disinfection: Ferrate(VI) as the Greenest Chemical-A Review. Applied Engineering, 3, 171-180.

[69] Ghernaout, D., Alghamdi, A., Touahmia, M., Aichouni, M. and Ait Messaoudene, N. (2018) Nanotechnology Phenomena in the Light of the Solar Energy. Journal of Energy, Environmental \& Chemical Engineering, 3, 1-8. https://doi.org/10.11648/j.jeece.20180301.11

[70] Ghernaout, D., Boudjemline, A. and Elboughdiri, N. (2020) Electrochemical Engineering in the Core of the Dye-Sensitized Solar Cells (DSSCs). Open Access Library Journal, 7, e6178.

[71] Ghernaout, D. and Elboughdiri, N. (2020) Electrocoagulation Process in the Context of Disinfection Mechanism. Open Access Library Journal, 7, e6083.

[72] Ghernaout, D., Badis, A., Ghernaout, B. and Kellil, A. (2008) Application of Electrocoagulation in Escherichia coli Culture and Two Surface Waters. Desalination, 219, 118-125. https://doi.org/10.1016/j.desal.2007.05.010

[73] Belhout, D., Ghernaout, D., Djezzar-Douakh, S. and Kellil, A. (2010) Electrocoagulation of a Raw Water of Ghrib Dam (Algeria) in Batch Using Iron Electrodes. Desalination and Water Treatment, 16, 1-9. https://doi.org/10.5004/dwt.2010.1081

[74] Ghernaout, D., Ghernaout, B. and Naceur, M.W. (2011) Embodying the Chemical Water Treatment in the Green Chemistry-A Review. Desalination, 271, 1-10. https://doi.org/10.1016/j.desal.2011.01.032

[75] Zhang, C., Li, Y., Shuai, D., Shen, Y. and Wang, D. (2019) Progress and Challenges in Photocatalytic Disinfection of Waterborne Viruses: A Review to Fill Current Knowledge Gaps. Chemical Engineering Journal, 355, 399-415. https://doi.org/10.1016/j.cej.2018.08.158

[76] Zheng, X., Shen, Z., Cheng, C., Shi, L., Cheng, R. and Yuan, D. (2018) Photocatalytic Disinfection Performance in Virus and Virus/Bacteria System by $\mathrm{Cu}-\mathrm{TiO}_{2}$ Nanofibers under Visible Light. Environmental Pollution, 237, 452-459.

https://doi.org/10.1016/j.envpol.2018.02.074

[77] Ghernaout, D., Elboughdiri, N., Ghareba, S. and Salih, A. (2020) Coagulation Process for Removing Algae and Algal Organic Matter-An Overview. Open Access Library Journal, 7, e6272. https://doi.org/10.4236/oalib.1106272

[78] Ghernaout, D., Ghernaout, B. and Kellil, A. (2009) Natural Organic Matter Removal and Enhanced Coagulation as a Link between Coagulation and Electrocoagulation. Desalination and Water Treatment, 2, 203-222.

https://doi.org/10.5004/dwt.2009.116

[79] Ghernaout, B., Ghernaout, D. and Saiba, A. (2010) Algae and Cyanotoxins Removal by Coagulation/Flocculation: A Review. Desalination and Water Treatment, 20, 133-143. https://doi.org/10.5004/dwt.2010.1202 
[80] Ghernaout, D. and Naceur, M.W. (2011) Ferrate(VI): In Situ Generation and Water Treatment-A Review. Desalination and Water Treatment, 30, 319-332. https://doi.org/10.5004/dwt.2011.2217

[81] Talaiekhozani, A., Talaei, M.R. and Rezania, S. (2017) An Overview on Production and Application of Ferrate (VI) for Chemical Oxidation, Coagulation and Disinfection of Water and Wastewater. The Journal of Environmental Chemical Engineering, 5, 1828-1842. https://doi.org/10.1016/j.jece.2017.03.025

[82] Ghernaout, D., Naceur, M.W. and Ghernaout, B. (2011) A Review of Electrocoagulation as a Promising Coagulation Process for Improved Organic and Inorganic Matters Removal by Electrophoresis and Electroflotation. Desalination and Water Treatment, 28, 287-320. https://doi.org/10.5004/dwt.2011.1493

[83] Ghernaout, D. (2014) The Hydrophilic/Hydrophobic Ratio vs. Dissolved Organics Removal by Coagulation-A Review. Journal of King Saud University-Science, 26, 169-180. https://doi.org/10.1016/j.jksus.2013.09.005

[84] Ghernaout, D., Al-Ghonamy, A.I., Boucherit, A., Ghernaout, B., Naceur, M.W., Ait Messaoudene, N., Aichouni, M., Mahjoubi, A.A. and Elboughdiri, N.A. (2015) Brownian Motion and Coagulation Process. American Journal of Environmental Protection, 4, 1-15. https://doi.org/10.11648/j.ajeps.s.2015040501.11

[85] Ghernaout, D., Ghernaout, B., Saiba, A., Boucherit, A. and Kellil, A. (2009) Removal of Humic Acids by Continuous Electromagnetic Treatment Followed by Electrocoagulation in Batch Using Aluminium Electrodes. Desalination, 239, 295-308. https://doi.org/10.1016/j.desal.2008.04.001

[86] Ghernaout, D., Ghernaout, B. and Boucherit, A. (2008) Effect of pH on Electrocoagulation of Bentonite Suspensions in Batch Using Iron Electrodes. Journal of Dispersion Science and Technology, 29, 1272-1275. https://doi.org/10.1080/01932690701857483

[87] Ghernaout, D., Ghernaout, B., Boucherit, A., Naceur, M.W., Khelifa, A. and Kellil, A. (2009) Study on Mechanism of Electrocoagulation with Iron Electrodes in Idealised Conditions and Electrocoagulation of Humic Acids Solution in Batch Using Aluminium Electrodes. Desalination and Water Treatment, 8, 91-99. https://doi.org/10.5004/dwt.2009.668

[88] Ling, F., Wang, J.G., Wang, G.X. and Gong, X.N. (2011) Effect of Potassium Ferrate(VI) on Survival and Reproduction of Ichthyophthirius multifiliis Tomonts. Parasitology Research, 109, 1423-1428. https://doi.org/10.1007/s00436-011-2389-1

[89] Ghernaout, D., Irki, S. and Boucherit, A. (2014) Removal of $\mathrm{Cu}^{2+}$ and $\mathrm{Cd}^{2+}$, and Humic Acid and Phenol by Electrocoagulation Using Iron Electrodes. Desalination and Water Treatment, 52, 3256-3270. https://doi.org/10.1080/19443994.2013.852484

[90] Irki, S., Ghernaout, D. and Naceur, M.W. (2017) Decolourization of Methyl Orange (MO) by Electrocoagulation (EC) Using Iron Electrodes under a Magnetic Field (MF). Desalination and Water Treatment, 79, 368-377. https://doi.org/10.5004/dwt.2017.20797

[91] Ghernaout, D. (2017) The Holy Koran Revelation: Iron Is a "Sent Down" Metal. American Journal of Environmental Protection, 6, 101-104. https://doi.org/10.11648/j.ajep.20170604.14

[92] Irki, S., Ghernaout, D., Naceur, M.W., Alghamdi, A. and Aichouni, M. (2018) Decolorization of Methyl Orange (MO) by Electrocoagulation (EC) Using Iron Electrodes under a Magnetic Field (MF). II. Effect of Connection Mode. World Journal of Applied Chemistry, 3, 56-64. https://doi.org/10.11648/j.wjac.20180302.13 
[93] Irki, S., Ghernaout, D., Naceur, M.W., Alghamdi, A. and Aichouni, M. (2018) Decolorizing Methyl Orange by Fe-Electrocoagulation Process: A Mechanistic Insight. Inter. Journal of Environmental Chemistry, 2, 18-28.

https://doi.org/10.11648/j.ijec.20180201.14

[94] Ghernaout, D., Alghamdi, A. and Ghernaout, B. (2019) Electrocoagulation Process: A Mechanistic Review at the Dawn of Its Modeling. Journal of Environmental Science and Allied Research, 2, 51-67.

https://doi.org/10.29199/2637-7063/ESAR-201019

[95] Ghernaout, D. (2017) Environmental Principles in the Holy Koran and the Sayings of the Prophet Muhammad. American Journal of Environmental Protection, 6, 75-79. https://doi.org/10.11648/j.ajep.20170603.13 